\title{
An Innovative Approach for the Assessment and Monitoring of Land Degradation and Desertification in Semi-Arid Regions Using Remote Sensing and GIS Techniques
}

\author{
Pradeep Kumar B \\ Yogi Vemana University \\ Raghu Babu K ( $\nabla$ dr.kraghu@gmail.com ) \\ Yogi Vemana University \\ Rajasekhar M \\ Yogi Vemana University \\ Sakram G \\ National Geophysical Research Institute CSIR \\ Ramachandra M \\ Yogi Vemana University
}

Research

Keywords: Desertification, Correlation, Soil parameters, DN values, RS, GIS

Posted Date: August 27th, 2020

DOI: https://doi.org/10.21203/rs.3.rs-56088/v1

License: (c) (i) This work is licensed under a Creative Commons Attribution 4.0 International License. Read Full License 


\section{Abstract}

Land degradation (LD) and desertification is a serious ecological, environmental, and social-economic threat in the world, and there is a demanding need to develop accountable and reproducible techniques to assess it at different scales. In this study to assess LD and desertification with the help of Remote Sensing (RS) and Geographical Information System (GIS) in the study region for the period of past 29 years i.e., from 1990 to 2019. The severity of LD and desertification was assessed quantitatively by collecting twelve soil samples in the study region, and analyzing the eleven soil Physico-chemical parameters and these values have made correlated with Digital Number (DN) values with LANDSAT 8 satellite image. The land cover analysis of LANDSAT imagery revealed that the water body slightly increased from $0.29 \%$ in 1990 to $0.46 \%$ in 2019 , and built-up-land increased from $2.87 \%$ in 1990 to $5.31 \%$ in 2019 . Vegetation is decreased from $52.03 \%$ in 1990 to $28.57 \%$. Fallow land, degraded land, and desertified lands are increased at alarming rates, respectively $13.71 \%$ to $26.35,18.57 \%$ to $22.31 \%$, and $12.53 \%$ to $17.00 \%$. It is also established that the multi-temporal analysis of change detection data can provide a sophisticated measure of ecosystem health and variation, and that, over the last 29 years, considerable progress has been made in the respective research.

\section{Introduction}

Desertification refers to land degradation (LD) in drylands, although over hundred definitions of desertification have been developed emphasizing different processes contributing to desertification, the United Nations Convention to Combat Desertification (UNCED) provides the most current, authoritative definition "land degradation in arid, semi-arid and dry subhumid areas resulting from various factors including climatic variations and human activities" (UNCED 1992). LD is a multifaceted phenomenon, it decreases soil fertility especially in semi-arid regions, and it leads to desertification occurrence. LD causes different aspects of natural resource depletion such as degradation of soil, waterbody, and vegetation.

Furthermore, LD has a negative influence on biophysical and socio-economic processes that society has defined as important components in various spatial and temporal scales (Kassas, 1999; Lal and Stewart, 1990; Garcia Latorre et al., 2001; Kumar. S et al.,2013; Rawat, Tao Han.; et al 2004; Ahmad, N., \& Pandey, P. 2018; Masoudi et al., 2018).

At the global scale, a different examination of satellite images appearances that the LD is a severe problem due to which 1.5 billion people threatened and 1.9 billion hectors of land and 250 million people are affected worldwide (Bai et al., 2008; Nachtergaele et al., 2010; Lam D.K et al., 2011). Coming to the National wide, nearly $32 \%$ of India's agricultural land is degraded and turning into deserts, and the rate of soil degradation is increasing day by day. A report by the Indian Space Research Organization (ISRO) says that LD now affects 96 million hectors or $30 \%$ of India's agricultural lands affected by this problem (NRSC 2010 and 2011). Most of this degradation was happening in the states of Jharkhand, Rajasthan, Delhi, Gujarat, Goa, Maharashtra, Jammu and Kashmir, Karnataka, Odisha, Madhya Pradesh, Andhra Pradesh and Telangana (Arya et al., 2014; Gautam et al., 2014; Pradeep et al., 2020a and b). Of these, the first five are facing desertification in more than 50 percent of their total area.

The change detection study deals with the comparison of satellite images of a region taken at different periods, performed on a temporal scale to access landscape change caused by anthropogenic activities on the land (Petit et al., 2001; Gibson and Power, 2000; Kumar. B. P. et al., 2019). Land Use and Land Cover (LULC) are often blended. This is somewhat logical for the reason that both terms are scarcely related and to more or less scope even overlap. In this normal state, land cover systematizes a faultless arrival of the environmental equilibrium among parent rock, climatic ailment, soil, and vegetation. landcover eminent into various categories i.e., area of vegetation, bare soil, rock outcrops, wet and water bodies, etc. in simple terms land cover is the result of observation. Land use denotes also to land cover but concerning its socio-economic persistence and global use (Harshika. A. K, et al 2012). This is in pure contrast with land cover as stated to above which is most expressive and deals with physical observations. Land use may differ in nature and intensity with both purposes it helps and with physical observations (A. M. Talha \& Dewan M.; et al 2009 \&2014). Land use varies from land cover for the reason that of the intentional role of people to familiarize the natural land cover to their assistance. 
Geospatial technologies, including GPS (Global Positioning System), Satellite imageries, and GIS hold great promising for improving the quality and quantity of information on degradation trends over large areas as well as provide for more effective management of that information. Furthermore, it is believed that dryland degradation can be slowed and reversed if areas undergoing desertification can be identified and properly managed (Kumar. B. P et al., 2020). The current research has also shown that RS and GIS can investigate temporal variations in desertification and land degradation, analyze changes amongst land cover features, develop baseline desertification maps, and also monitor desertification (Kumar. S et al., 2014).

In addition to LD, desertification assessment and land use land cover dynamics, this exploration also comprises the study of spatial variability in soil parameters (Raina et al.,1999; Ahmad, N., \& Pandey, P. 2018) like pH, EC, Soil organic matter(SOM), Nitrogen (N), Phosphorus (P), Potassium (K), Iron (Fe), Zinc (Zn), Copper (Cu), and Manganese (Mn), and Sulfur using the digital soil mapping Inverse Distance Weighted (IDW) method in irrigated and non-irrigated soils of Bommanahal Mandal of Anantapur district, Andhra Pradesh state, India. The results obtained by both approaches have been correlated to get a better picture of the extent of degraded lands and desertified lands in the semi-arid region in southern India.

\subsection{Study area}

Bommanahal region of Anantapur district of Andhra Pradesh, India, with an area of $305.86 \mathrm{Km}^{2}$. This region is located in between the "longitude of $76^{\circ} 52 \rrbracket$ and $77^{\circ} 08 \otimes$ and latitude of $14^{\circ} 48 \rrbracket$ and $15^{\circ} 04 \rrbracket$ (Fig. 1). The climate of the study region varies from semi-arid to sub-humid and being positioned in the rain shadow area of Western Ghats, in the interior of Deccan plateau, having low rainfall of about $520 \mathrm{~mm}$ is lowest in the state and recognized as second driest part in the country next to Jaisalmer, and is one of the chronic drought-affected regions in the country". This region experiences a tropical climate, in summer seasons continuous from March to May, the temperature varies from 24 to $46^{\circ} \mathrm{C}$.

Lithologically the current study region having two distinct and well-marked groups of older groups of metamorphic rocks belongs to the Archean age and younger groups of sedimentary rocks belong to the Proterozoic age (Figure. 2a). Grey/Pink granites, Hornblende - biotite gneiss, Migmatites, and Quartzite's (BMQ and BIF) are the common rock types existing in the study region (Pradeep Kumar et al., 2017, 2018; Rajasekhar et al., 2018).

Active geomorphic changes have been caused by the action of wind (aeolian action) in this region. Hagari/Vedavathi flowing through the center of the study region and it is the ephemeral river, hence it has dry during most of the year (Figure. 2b). Because of high-speed winds causing by the southwestern monsoon season ( 34 to $38 \mathrm{~km} / \mathrm{h}$ ) between June to August, the sand and dunes present on the side of the river banks get migrated to the agricultural fields and the land has been degraded and finally desertified.

\section{Materials And Methods}

\subsection{Data used:}

Supplementary data like SOI (Survey of India) topo sheets of 57A/16, 57B/13, 57E/4, and $57 \mathrm{~F} / 1$ with 1:50000 scale and the latest satellite data of LANDSAT imageries of the year 1990, 2000, 2010 and 2019 were procured freely from the USGS earth explorer website (http://www.usgs.gov) and Earth Resources Data Analysis System (ERDAS) software has been used for satellite image processing techniques, and ArcGIS 10.4, Environmental System Research Institute (ESRI) product remained castoff to progression, classify and pageant the satellite images.

\subsection{Land use / Land cover (LULC)}

False Colour Composite (FCC) of multi-temporal satellite imageries of the years 1990, 2000, 2010, and 2019 were collected and layer stacked in ERDAS software, with a 1:50000 scale. Besides, the unsupervised classification method is adoptable in the ERDAS, in that the main digital value for each input band could be signified as a spectral reflectance profile and spectral variability in class. Afterward, the classification has been finished each class should be observed and allocated a name it may also be necessary to merge several classes into a single category. To finish, the LULC map was prepared with supervised 
classification using the maximum likelihood classification algorithm (MLC). The objective is to encompass or extrapolate info on land cover types for an acknowledged area of the image to the unidentified areas of the whole image.

\subsection{Physico - Chemical analysis of Soil}

Eleven chemical parameters - "pH, EC, Soil organic matter (SOM), Nitrogen (N), Phosphorus (P), Potassium (K), Iron (Fe), Zinc $(\mathrm{Zn})$, Copper $(\mathrm{Cu})$, and Manganese (Mn) and sulfur (S)", were analyzed for 12 soil samples in the study region as represented in Table 1 with locations and parameters values. Figure $2 \mathrm{c}$ represents the location of soil samples collected in the study region. The chemical parameters $\mathrm{pH}, \mathrm{EC}, \mathrm{SOM}, \mathrm{N}, \mathrm{P}, \mathrm{K}, \mathrm{Zn}, \mathrm{Mn}, \mathrm{Fe}, \mathrm{Cu}, \mathrm{S}$, and $\mathrm{B}$ of the soils samples collected from the sampling sites in the study region are given in Table 1. The $\mathrm{pH}$ was determined following the procedure of IS:2720, part 11983 in which a pH meter (MT-103 Delux) was used to record the pH in an extract of soli or supernatant liquid (ICAR, 2010; Indian Standard, 1987). The EC was carried out in EC conductivity meter (Indian Standard, 2000). An extract of soil water suspension was prepared and filtered using filter paper to avoid any interference before recording the conductivity with EC meter. The parameters of $\mathrm{Zn}, \mathrm{Mn}, \mathrm{Fe}$, and Cu were determined by the titration method, in that soil added to DTPA into 1:2 ratios and then the sample has been placed into Atomic Absorption Spectra Photometer (Mathew, 2014; Indian standard, 2000; Gupta. P.K, 2007). The parameter B and S have been determined by using Micro calorimeter. The parameter $\mathrm{K}$ has been determined in the Systronic flame photometer and P has been determined in Systronic Digital balanced cell calorimeter (Costa et al., 2015).

\subsection{IDW interpolation method for Soil mapping}

LD and desertification that remained exposed in quantifiable terms are delineated in the GIS environment utilizing statistical analysis in ArcGIS. There are numerous interpolation methods such as Kriging and Inverse Distance Weighted (IDW) that guesstimate the cell values by averaging the values of samples data points in the district of each processing cells (Sheng, 2010; Liu, 2016; Lillesand et al., 1994). IDW technique was adopted for the preparation of soil maps, it is used to approximate the variable parameters like PH, Ec, SOM, N, P, K, Fe, Zn, Cu, and Mn. The IDW is one of the typically applied and deterministic interpolation techniques in the field of soil science. IDW evaluations were based on nearby known locations (Mora - Vallejo, 2008; Ahmad, N., \& Pandey, P. 2018). The weights assigned to the interpolating point are the inverse of its distance from the interpolation point.

\section{Results And Discussion}

\subsection{LULC classification}

The False Colour Composite (FCC) imageries were prepared for the 1990 LANDSAT satellite data using the band combination of "RGB 432" (Figure. 3a). FCC for the year 2000 LANDSAT ETM+ satellite data using band combination of "RGB 432" (Figure. $3 b)$. For the 2010 LANDSAT satellite data, FCC band combination is "RGB 764" (Figure. 3c) while the band combination for the LANDSAT 8 satellite image for 2019 (Figure. 3d). After the preparation of FCCs and visual interpretation, LULC maps of the study region were prepared by using the unsupervised classification for 1990, 2000. 2010 and 2019 as shown in Figure. 4a, Figure. 4b, Figure. 4c, and Figure. 4d using the ISODATA technique.

After unsupervised classification, in which insights were gained about spectral variability in class, supervised classification of FCC images both the temporal database of LANDSAT images was carried out for 1990, 2000, 2010, and 2019 as given in Figure. 5a, Figure. 5b, Figure. 5c, and Figure. 5d using the Maximum Likelihood Classification.

\subsection{Change detection analysis}

To analyze changes for the period of past 29 years, supervised images of 1990, 2000, 2010, and 2019 were used as input images and the change detection of the present study region is shown in Table 2 in terms of $\mathrm{Km}^{2}$ and percentage. The supervised images for 1990, 2000, 2010, and 2019 were shown in Figures 5a, 5b, 5c, and 5d respectively. LULC change detection is classified into six categories namely vegetation, fallow lands, degraded lands, desertified lands, water body, and 
built-up lands. Usually, vegetation / agricultural texture is red color in the satellite imageries. For this LULC mapping, four dissimilar LANDSAT imageries (1990, 2000, 2010, and 2019) were collected and adopted to supervised classification and done mapping with the given color to red. In the year 1990 vegetation is $159.12 \mathrm{~km}^{2}(52.03 \%)$ is noticed. When coming to the year 2000 vegetation is decreased to $118.51 \mathrm{~km}^{2}$ (38.75\%) and in the years 2010 and 2019 it is also decreased to $109.90 \mathrm{~km}^{2}$ (35.93\%), $37.38 \mathrm{~km}^{2}$ (28.57\%) respectively. Fallow land is in olive color in the supervised images. In the year 1990 fallow land is noticed as $41.93 \mathrm{~km}^{2}(13.71 \%)$ and in the year 2000, it is increased to $73.96 \mathrm{~km}^{2}$ (24.18\%). In the year 2010, it is decreased to $70.92 \mathrm{~km}^{2}(23.19 \%)$ and in the year 2019 , it is increased to $80.60 \mathrm{~km}^{2}(26.35 \%)$. Degraded land is also called as barren land in the LULC classification. Here degraded land is noticed in the year 1990 as $56.79 \mathrm{~km}^{2}(18.57 \%)$ and it is gradually increased for the years 2000,2010 , and 2019 to $62.93 \mathrm{~km}^{2}$ (20.57\%), $65.94 \mathrm{~km}^{2}(21.56 \%)$, and $68.25 \mathrm{~km}^{2}(22.31 \%)$ respectively. Coming to the desertified lands, active geomorphic changes take place in this study region. the wind is the geomorphological agent in the transportation or enhancement of dunes in the study part. Dune migration leads to an ecosystem imbalance in the study part. This leads the study part to be faced with desertification conditions and finally to be desertified. The yellow color is given to the desertified lands category in the supervised image. In the year 1990 it is noticed as $8.80 \mathrm{~km}^{2}(2.87 \%)$ and in the year 2000, 2010, and 2019 it is continuously increased to $40.32 \mathrm{~km}^{2}(13.18 \%), 44.91 \mathrm{~km}^{2}(14.68$ $\%)$, and $51.99 \mathrm{~km}^{2}(17.00 \%)$. Waterbodies are given to blue color in the supervised image. In the year 1990 waterbodies are noted as $0.89 \mathrm{~km}^{2}(0.29 \%)$ and in the year 2000,2010 , and 2019 it is positively increased to $0.97 \mathrm{~km}^{2}(0.32 \%), 1.02 \mathrm{~km}^{2}(0.33$ $\%)$, and $1.41 \mathrm{~km}^{2}(0.46 \%)$ respectively. Built-up land is given as green in color in the supervised imagery. In the year 1990 it is noticed as $49.31 \mathrm{~km}^{2}(14.48 \%)$ and it is gradually increased for the years 2000,2010 , and 2019 as $9.17 \mathrm{~km}^{2}(3.00 \%)$, $13.17 \mathrm{~km}^{2}(4.31 \%)$, and $16.23 \mathrm{~km}^{2}(5.31 \%)$ respectively.

Table 3 labels the change detection in the total area ( $\mathrm{km}^{2}$ and percentage) covered by different LULC between the years 1990 and 2019 procured from LANDSAT satellite data. The area under waterbody is slightly increased to $0.52 \mathrm{~km}^{2}(0.17 \%)$, and the Built-up land is extended to $7.43 \mathrm{~km}^{2}$ (2.42\%). Vegetation is decreased to $71.76 \mathrm{~km}^{2}$ (23.46\%). Fallow land, Degraded lands, and Desertified lands showed increasing in trend to $38.67 \mathrm{~km}^{2}$ (12.64\%), $11.46 \mathrm{~km}^{2}$ (3.74\%), and $13.68 \mathrm{~km}^{2}$ (4.47\%) (Fig 5b).

\subsection{Soil Parameters analysis}

Spatial erraticism of specific soil properties in the study region was predicted by digital soil mapping, these maps were produced in digital format in a rapid, efficient, operative, and little cost method. LD and desertification were shown as the spatial distribution of all the eleven in quantifiable terms via IDW interpolation methods using ArcGIS software-based statistical analysis tools (Sheng, 2010). Grounded on the $\mathrm{pH}$ values, a soil map for sampling sites was composed of the software ArcGIS 10.4 (Fig 6a). similarly, based on EC, SOM, N, P, K, Zn, Mn, Fe, Cu, and S values, soil maps were self-possessed as shown in Fig. 6b, c, d, e, f, g, h, l, j, and k, correspondingly, portraying the severity of LD and desertification in terms of soil parameters.

Areas like Nemakallu, Unthakallu, Uddehal, Bommanahal, Kuruvalli, of the North-Western (NW) part of the selected part exhibited a huge proportion of soils that were alkali or sodic, South-Eastern (SE) areas like Govindavada, Honnuru were calcareous or saline in nature, Bollanaguddam, Kalludevanahalli, Kuruvalli areas of north-eastern parts (NE) shows slightly to saline in nature. There is no acidic sample were traced in the study region (Fig 6a). Grounded on the EC standards, it has detected from the map (Fig .6b) that in the selected part, the maximum study part occupied by somewhat a little saline, and around of the south-western (SW) regions like Elanji and Kodaganahalli remained abstemiously saline. Founded on SOM ranges, it has detected from the map area (Fig .6c) that in the study, the maximum study area was high SOM likely 0.45-0.53. Founded on the NPK values, it is observed from the maps (fig .6d, 6e, 6f) that in the study area, deficiency of N is traced in NW and NE parts, deficiency of $\mathrm{P}$ is traced in SW part and moderate values in EW part, and lower in $\mathrm{K}$ values throughout the study region. Based on Zn values, it has observed from the map (Fig .6g) lower in the NE part and higher in the SW part. Founded on $\mathrm{Mn}$ values, it has observed from the map (Fig .6h) moderate throughout the region and NE part having variation in their values to moderate to high, based on Fe values, it has observed from the map (Fig. 6i), NE-SW Part of the study regions shows high iron content in the soils and remaining area having moderate values, based on Cu values, it has observed from the map (Fig 
$.6 \mathrm{j})$, lower values in the NE part and moderate in the center of the study region. Based on $\mathrm{S}$ values, it has observed from the map (Fig .6k), SE, and SW parts having low values and NW part having moderate and center of the study region showing high values.

\subsection{Correlation between Physico-chemical parameters}

To determine the relationship between the soil salinity and DN values for the total pixels of the different soils, an effort was completed to intercalate the soil salinity data. To interpolate the available soil salinity data, for the 11 soil samples have been observed with different soil parameter observations at the topsoil derived from soil mapping were digitized and then rasterized. The rasterized map was then interpolated using ArcGIS software which performs IDW based on the values of soil parameters. The correlation examination has been given in Table 3. "Based on the results attained from the soil analysis, an attempt was made to establish correlation for band 3 (green), band 5 (NIR), and band 7 (SWIR) of the LANDSAT 8 satellite image for the year 2019 with 11 soil parameters ( $\mathrm{pH}, \mathrm{EC}, \mathrm{SOM}, \mathrm{N}, \mathrm{P}, \mathrm{K}, \mathrm{Zn}, \mathrm{Mn}, \mathrm{Fe}, \mathrm{Cu}$, and S), the DN of corresponding sites was statistically correlated with Physico-chemical parameters at the 0.5 significance level. There is no significant relation between visible band 3 and SWIR band 7 of the satellite image, hence those values are not mentioned here. The DN values used in the correlation matrix were the same as the values of band 5 (NIR)". Nonetheless unveiled insignificant correlation with Physico-chemical parameters linked to the rest of the bands of the pixels for the 2019 image (Ahmad, N., \& Pandey, P. 2018).

Rendering to our outcomes, the correlation between coefficient amongst the soil salinity and related DN values using LANDSAT data was supportive in calculating the significant relation between satellite data and soil salinity. The salt-affected soils in semi-arid regions show a high reflectance, especially when a salt crust (whitish color) is formed. For the assessment of LD and desertification, the correlation between DN's and Soil parameters by concocting soil maps from remotely sensed data.

\section{Conclusions}

In this study, we make an effort to assess and map the land degradation, desertification changes, and soil characteristics in the semi-arid area of the ATP district of AP, India between the years 1990 to 2019 using the combined technique of RS and GIS modeling. We found that there is a positive sign that the increase in water bodies is noticed $0.52 \mathrm{Km}^{2}$ or 52 hectares. Built-up areas lengthened around $7.43 \mathrm{Km}^{2}$ or 743 hectares between 1990 to 2019 . The land under vegetation is decreased from $159.14 \mathrm{Km}^{2}$ to $87.38 \mathrm{~km}^{2}$, which means 7176 hectares of vegetation land is decreased. Fallow land is increased from $41.93 \mathrm{~km}^{2}$ to $80.60 \mathrm{~km}^{2}$, which means 3867 hectares of land is uncultivated in this region, this leads to degradation increase in the land. Degraded land is also increased from $56.79 \mathrm{~km}^{2}$ to $68.25 \mathrm{~km}^{2}$, the resultant changes are $11.46 \mathrm{~km}^{2}$ or 1146 hectares. LD leads to desertification in the study region, it is increased in alarming rates from $38.31 \mathrm{~km}^{2}$ to $51.99 \mathrm{~km}^{2}$, in other words, $13.68 \mathrm{~km}^{2}$ or 1318 hectares of agricultural lands converted into deserts. Because of the desertification conditions, most people stop their agricultural forming and get migrated to other cities for their livelihood.

The soil Physico-chemical analysis provides to be very useful in assessing the degree of soil-salinization, most of the regions had moderate to saline type. Correlation studies examining the response amongst the spectral response of the soil and physio-chemical parameters revealed that band 5 (NIR) was better indicators of soil. Hence, the usage of multispectral remotely sensed data in a GIS environment to assess the amount of LD and desertification can assistance in the direction of the renovation of the degradation of land resources and their conservation. The current work is very useful for the identification of hotspots of degradation, and taking the action plans to control the desertification at global scales. The RS and GIS provide pointers on tools to monitor, approximation, appraise achieve, and supervisory factor the environmental imperils to save life and society.

\section{List Of Abbreviations}


LD: Land degradation; RS: Remote Sensing; GIS: Geographic Information System; DN: Digital Number; UNCED: United Nations Convention to Combat Desertification; ISRO: Indian Space Research Organization; LULC: Land Use and Land Cover; IDW: Inverse Distance Weighted; ERDAS: Earth Resources Data Analysis System; ESRI: Environmental System Research Institute; MLC: Maximum likelihood Classification Algorithm; FCC: False Colour Composite;

\section{Declarations}

Availability of data and material (Available on request)

\section{Conflicts of interest/Competing interests (N/A)}

\section{Funding Sources}

Department of Science and Technology (DST), Government of India, for financial support through Inspire program (Sanction order No. DST/INSPIRE Fellowship/2017/IF170114).

\section{Conflict of Interest}

The authors declare no conflict of interest.

\section{Code availability (N/A)}

Authors' contributions (Dr.K.Raghu Babu - Principal Investigator, B.Pradeep Kumar, M.Rajasekhar and M.Ramachandra Research Analysis and Drafting and G.Sakram - Interpretation Data)

\section{References}

1. Ahmad, N., \& Pandey, P. (2018). Assessment and monitoring of land degradation using geospatial technology in Bathinda district, Punjab, India. Solid Earth, 9(1).

2. Anees, M. T., Javed, A., \& Khanday, M. Y. (2014). Spatio-temporal land cover analysis in Makhawan Watershed (MP), India through remote sensing and GIS techniques. Journal of Geographic Information System, 2014.

3. Arya, A. S., Dhinwa, P. S., Pathan, S. K., \& Raj, K. G. (2009). Desertification/land degradation status mapping of India. Current Science, 1478-1483.

4. Bai, Z. G., Dent, D. L., Olsson, L., \& Schaepman, M. E. (2017). Global assessment of land degradation and improvement 1: identification by remote sensing.

5. Costa, J. L., Aparicio, V., \& Cerda, A. (2014). Soil physical quality changes under different management systems after 10 years in Argentinian humid pampa. Solid Earth Discuss, 6, 2615-2644. https://doi.org/10.5194/se-6-361-2015, 2015.

6. Dewan, A. M., \& Yamaguchi, Y. (2009). Land use and land cover change in Greater Dhaka, Bangladesh: Using remote sensing to promote sustainable urbanization. Applied geography, 29(3), 390-401.

7. Gautam, N.C. and Narayan, L.R.A., (2014) Wastelands in India, Pink Publishing House, Mathura, India, pp.96.

8. Gupta, P. K., \& Gupta, P. K. (2007). Methods in environmental analysis: water, soil and air (pp. 5-127). Jodhpur, India: Agrobios.

9. Harshika, A. K.; and Sopan I. Land Use Land Cover Classification and Change Detection Using High Resolution Temporal Satellite Data, Journal of Environment: Vol. 01, Issue 04, pp. 146-15, 2012.

10. ICAR (Indian Council of Agricultural Research): State of Indian Agriculture, 2012-2013, Areport of Department of Agriculture and Cooperation, New Delhi, 9, 2010.

11. IS (Indian Standard): Methods of test for soils, Department of pH value, IS:2720-1, 1983, Bureau of Indian Standards, New Delhi, India, 1987. 
12. IS (Indian Standard): Method of test for Soils, Determination of the specific electrical conductivity of Soils, IS:14767-2000, Bureau of Indian Standards, New Delhi, India, 2000.

13. Kassas, M. (1999). Rescuing drylands: a project for the world. Futures, 31(9-10), 949-958.

14. Kumar, S. S., Arivazhagan, S., \& Rangarajan, N. (2013). Remote Sensing and GIS Applications in Environmental SciencesA Review. J. Environ. Nanotechnol, 2(2), 92-101.

15. Kumar. B.P., Babu, K.R., Rajasekhar, M. and Ramachandra M. Identification of land degradation hotspots in semiarid region of Anantapur district, South India, Using geospatial modeling approaches. Model. Earth Syst. Environ. 6, 18411852 (2020a). https://doi.org/10.1007/s40808-020-00794-x

16. Kumar. B. P., Babu, K. R., Ramachandra, M., Krupavathi, C., Swamy, B. N., Sreenivasulu, Y., \& Rajasekhar, M. (2020b). Data on identification of desertified regions in Anantapur district, Southern India by NDVI approach using remote sensing and GIS. Data in Brief, 105560.

17. Kumar, B. P., Babu, K. R., Rajasekhar, M., \& Ramachandra, M. (2019). Assessment of land degradation and desertification due to migration of sand and sand dunes in Beluguppa Mandal of Anantapur district (AP, India), using remote sensing and GIS techniques. J. Ind. Geophys. Union (March 2019), 23(2), 173-180.

18. Kumar, P., Raghu Babu, K., Rajasekhar, M., Narayana Swamy, B., \& Ramachandra, M. (2019). Landuse/Landcover Changes and Geo-Environmental Impacts on Beluguppa Mandal of Anantapur District of Andhra Pradesh, India, using Remote Sensing and GIS Modelling. Research \& Reviews: Journal of Space Science \& Technology, 8(2), 6-15.

19. Lal, R. (1990). Soil erosion and land degradation: the global risks. In Advances in soil science (pp. 129-172). Springer, New York, NY.

20. Lam, D. K., Remmel, T. K., \& Drezner, T. D. (2011). Tracking desertification in California using remote sensing: A sand dune encroachment approach. Remote Sensing, 3(1), 1-13.

21. Latorre, J. G., García-Latorre, J., \& Sanchez-Picón, A. (2001). Dealing with aridity: socio-economic structures and environmental changes in an arid Mediterranean region. Land use policy, 18(1), 53-64.

22. Lillesand, T. M. and Kiefer, R. W.: Remote Sensing and Image interpretation, $3^{\text {rd }}$ edn., John Wiley and Sons, New York, 161163, 1994.

23. Liu, W., Du, P., Zhao, Z., \& Zhang, L. (2016). An adaptive weighting algorithm for interpolating the soil potassium content. Scientific reports, 6(1), 1-11, https://doi.org/10.1038/srep23889, 2016.

24. Masoudi, M., Jokar, P., \& Pradhan, B. (2018). A new approach for land degradation and desertification assessment using geospatial techniques. Natural Hazards and Earth System Sciences.

25. Mathew, J.: Wizard Geography for General studies, $7^{\text {th }}$ ed., Career Classics, New Delhi, India, 55, 2014.

26. Mora-Vallejo, A., Claessens, L., Stoorvogel, J., \& Heuvelink, G. B. (2008). Small scale digital soil mapping in Southeastern Kenya. Catena, 76(1), 44-53.

27. Nachtergaele, F., Petri, M., Biancalani, R., Van Lynden, G., Van Velthuizen, H., \& Bloise, M. (2010). Global land degradation information system (GLADIS). Beta version. An information database for land degradation assessment at global level. Land degradation assessment in drylands technical report, 17.

28. NRSC and Ministry of rural development (2010) wastelands atlas of India, 2010, Hyderabad: National remote Sensing Cater, dept. of Space Government of India.

29. NRSC (2011) Land Use Land Cover Atlas of India based on multi -temporal satellite data of 2005-06: National Remote Sensing Center, ISRO, Dept. of Space, Government of India.

30. Rajasekhar M., Sudarsana. Raju G., Siddi Raju, R., Ramachandra, M. and B. Pradeep Kumar, B., 2018. Data in Brief Data on comparative studies of lineaments extraction from ASTER DEM, SRTM, and Carto sat for Jilledubanderu River basin, Anantapur district, AP, India by using remote sensing and GIS. Data in Brief, 20(2018): 1676-1682.

31. Raina, P. (1999). Soil degradation assessment through remote sensing and its impact on fertility status of soils of western Rajasthan. Agropedology, 9, 30-40. 
32. Rawat, J. S., Biswas, V., \& Kumar, M. (2013). Changes in land use/cover using geospatial techniques: A case study of Ramnagar town area, district Nainital, Uttarakhand, India. The Egyptian Journal of Remote Sensing and Space Science, 16(1), 111-117.

33. Sheng, J., Ma, L., Jiang, P. A., Li, B., Huang, F., \& Wu, H. (2010). Digital soil mapping to enable classification of the saltaffected soils in desert agro-ecological zones. Agricultural Water Management, 97(12), 1944-1951.

34. Tao Han, "Some Research Advances and Methods on Detecting Land Cover Change by Remote Sensing," Arid Meteorology, 2004, 22ð2邓: 76-81.

35. UNCED, 1992: Earth summit agenda 21: programme of Action for Sustainable Development. United Nations Department of Public Information.

\section{Tables}

Table 1

Soil Physico-chemical parameters.

\begin{tabular}{|c|c|c|c|c|c|c|c|c|c|c|c|c|c|}
\hline $\begin{array}{l}\text { S. } \\
\text { No }\end{array}$ & Latitude & Longitude & $\mathrm{pH}$ & EC & SOM & $\mathbf{N}$ & $\mathbf{P}$ & $\mathrm{K}$ & $\mathrm{Zn}$ & Mn & $\mathrm{Fe}$ & $\mathrm{Cu}$ & $S$ \\
\hline 1 & $.57 " \mathrm{~N}$ & "E & 8 & 0 & & 108 & 70 & 4 & 4 & 62 & 2 & .25 & 20 \\
\hline 2 & $14^{\circ} 56^{\prime}$ & 1928 & 7.8 & (u & 0.2 & 104 & 27 & 120 & 4 & 2.04 & 89 & 52 & 43 \\
\hline 3 & $14^{\circ} 56^{\prime} 12.67^{\prime \prime} \mathrm{N}$ & & 7.86 & 0.11 & 0.5 & 104 & 13 & 272 & 0.546 & 2.87 & 2.64 & 0.31 & 13 \\
\hline 4 & $14^{\circ} 56^{\prime} 21.23^{\prime \prime} \mathrm{N}$ & $77^{\circ} 5^{\prime} 25.76 " \mathrm{E}$ & 8.05 & 0.06 & 0.62 & 148 & 27 & 760 & 0.62 & 2 & 4.64 & 0.28 & 6 \\
\hline 5 & $14^{\circ} 55^{\prime} 42.40^{\prime \prime} \mathrm{N}$ & $77^{\circ} 3^{\prime} 47.07^{\prime \prime} \mathrm{E}$ & 7.82 & 0.05 & 0.2 & 106 & 17 & 96 & 0.00 & & 2.14 & 0.5 & 7 \\
\hline 6 & $14^{\circ} 54^{\prime} 50.33^{\prime \prime} \mathrm{N}$ & 77 & 7.88 & 0.09 & 0.29 & 107 & 2 & 184 & 0.35 & & 3 & 0.28 & 7 \\
\hline 7 & ${ }^{\circ} 53^{\prime} 52.56 " \mathrm{~N}$ & $77^{\circ} 5^{\prime} 35.19 " \mathrm{E}$ & 7.92 & 0.06 & 0 & 104 & 58 & 200 & 0 & 2 & & 0.25 & 10 \\
\hline 8 & $14^{\circ} 55^{\prime} 15.21 " \mathrm{~N}$ & $77^{\circ} 5^{\prime} 41.75^{\prime \prime} \mathrm{E}$ & 7.81 & 0.04 & 0. & 104 & 37 & 120 & 0. & 4. & 2.14 & 0.63 & 4 \\
\hline 9 & $14^{\circ} 58^{\prime} 41.50 " \mathrm{~N}$ & $77^{\circ} 0^{\prime} 2.55^{\prime \prime} \mathrm{E}$ & 8.33 & 0.09 & 0.49 & 98 & 39 & 112 & 0.52 & 2.64 & 2.5 & 0.46 & 14 \\
\hline 10 & $14^{\circ} 55^{\prime} 14.46 " \mathrm{~N}$ & $76^{\circ} 59$ & 8.3 & 0.05 & 0 & 108 & 30 & 152 & 0.72 & 2.89 & 4.86 & 0.43 & 9 \\
\hline 11 & $14^{\circ} 54^{\prime} 07.14^{\prime \prime} \mathrm{N}$ & $76^{\circ} 56^{\prime} 40.33^{\prime \prime} \mathrm{E}$ & 7.87 & 0.05 & 0.6 & 108 & 16 & 216 & 0.43 & 2.89 & 5.03 & 0.38 & 6 \\
\hline 12 & $15^{\circ} 00^{\prime} 4.39^{\prime \prime} \mathrm{N}$ & $76^{\circ} 55^{\prime} 50.84^{\prime \prime} \mathrm{E}$ & 8.18 & 0.06 & 0.39 & 97 & 41 & 184 & 0.49 & 2.83 & 5.81 & 0.38 & 24 \\
\hline
\end{tabular}

Table 2

LULC classification for the years 1990, 2000, 2010, and 2019.

\begin{tabular}{|lllllllll|}
\hline LULC & $\mathbf{1 9 9 0}$ & \multicolumn{3}{c}{$\mathbf{2 0 0 0}$} & \multicolumn{2}{c}{$\mathbf{2 0 1 0}$} & \multicolumn{2}{c|}{2019} \\
\cline { 2 - 9 } categories & $\mathrm{Km}^{2}$ & Percentage & $\mathrm{Km}^{2}$ & Percentage & $\mathrm{Km}^{2}$ & Percentage & $\mathrm{Km}^{2}$ & Percentage \\
\hline Waterbodies & 0.89 & 0.29 & 0.97 & 0.32 & 1.02 & 0.33 & 1.41 & 0.46 \\
\hline Built up land & 8.80 & 2.87 & 9.17 & 3.00 & 13.17 & 4.31 & 16.23 & 5.31 \\
\hline Vegetation & 159.14 & 52.03 & 118.51 & 38.75 & 109.90 & 35.93 & 87.38 & 28.57 \\
\hline Fallow land & 41.93 & 13.71 & 73.96 & 24.18 & 70.92 & 23.19 & 80.60 & 26.35 \\
\hline Degraded land & 56.79 & 18.57 & 62.93 & 20.57 & 65.94 & 21.56 & 68.25 & 22.31 \\
\hline Desertified land & 38.31 & 12.53 & 40.32 & 13.18 & 44.91 & 14.68 & 51.99 & 17.00 \\
\hline & 305.86 & 100 & 305.86 & 100 & 305.86 & 100 & 305.86 & 100 \\
\hline
\end{tabular}


Table 3

Resultant changes from 1990 to 2019.

\begin{tabular}{|lll|}
\hline LULC categories & \multicolumn{2}{l|}{ Changes from 2000-2019 } \\
\cline { 2 - 3 } & $\mathrm{Km}^{2}$ & Percentage \\
\hline Waterbodies & 0.52 & 0.17 \\
\hline Built upland & 7.43 & 2.42 \\
\hline Vegetation & -71.76 & -23.46 \\
\hline Fallow land & 38.67 & 12.64 \\
\hline Degraded land & 11.46 & 3.74 \\
\hline Desertified land & 13.68 & 4.47 \\
\hline
\end{tabular}

Table 3

Correlation between the digital number of NIR band and soil parameters.

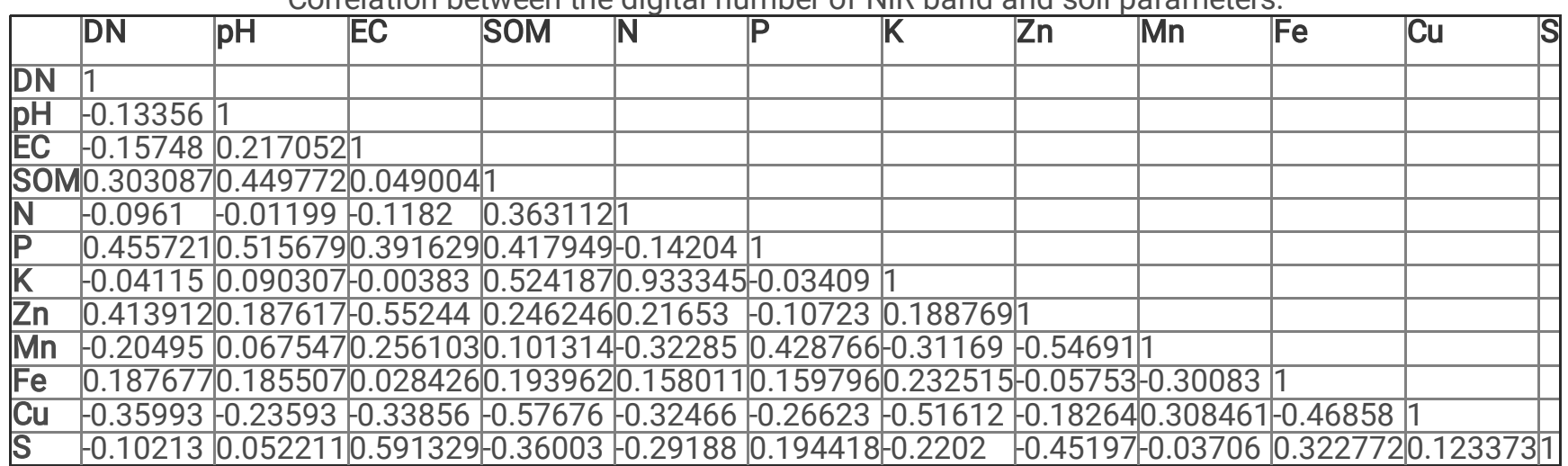

Figures 


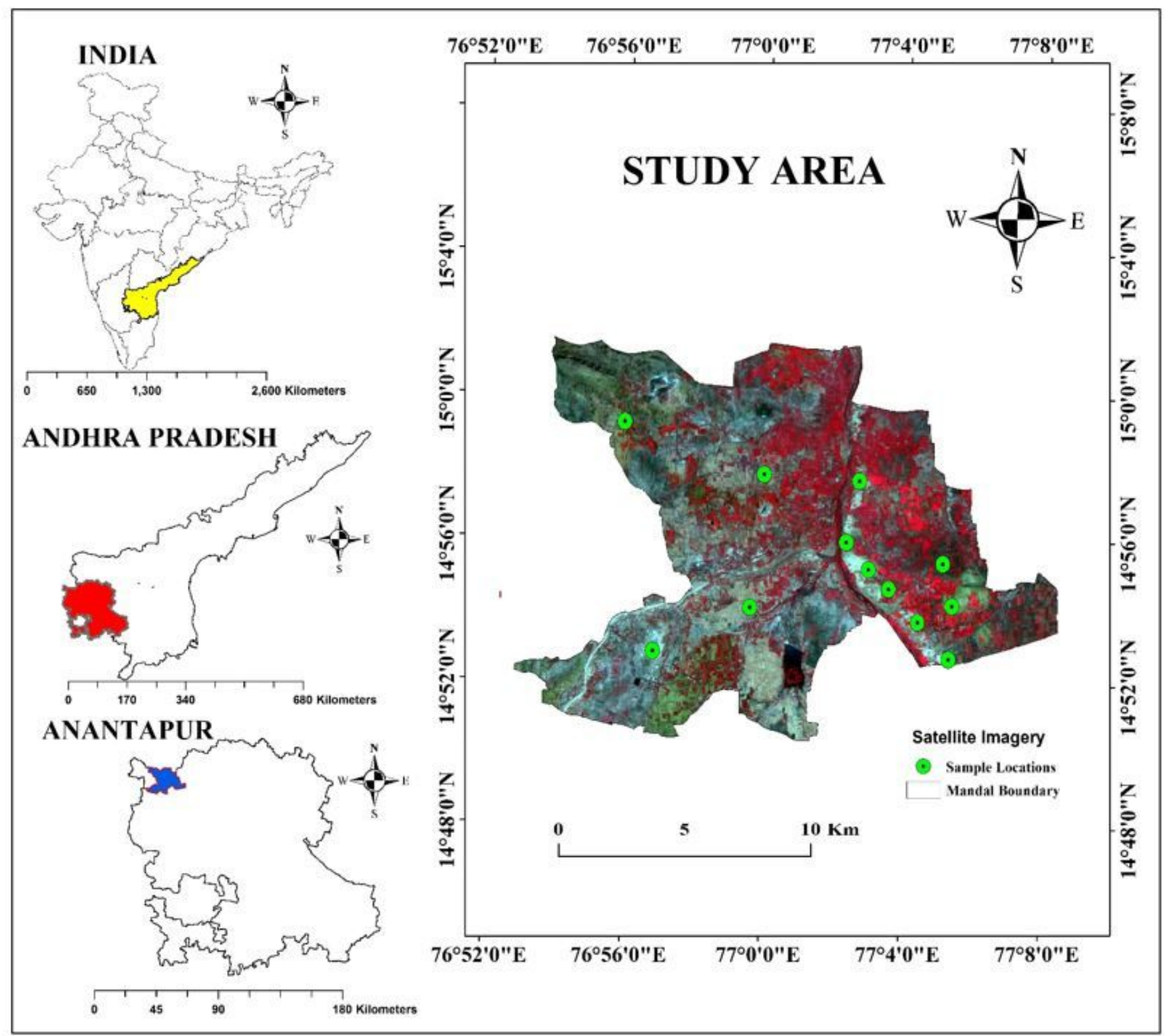

Figure 1

Location map 


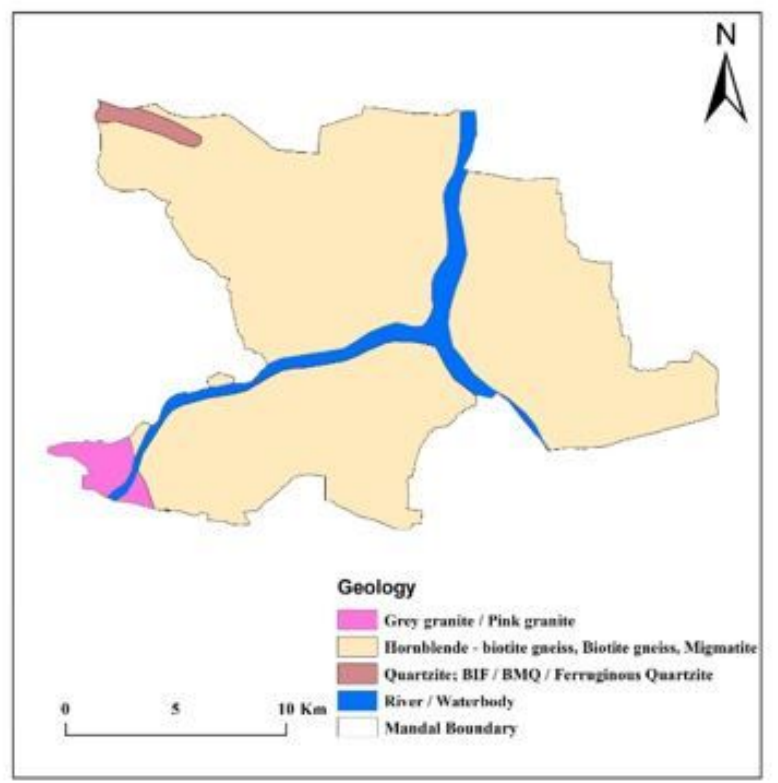

Figure 2

a: Geology

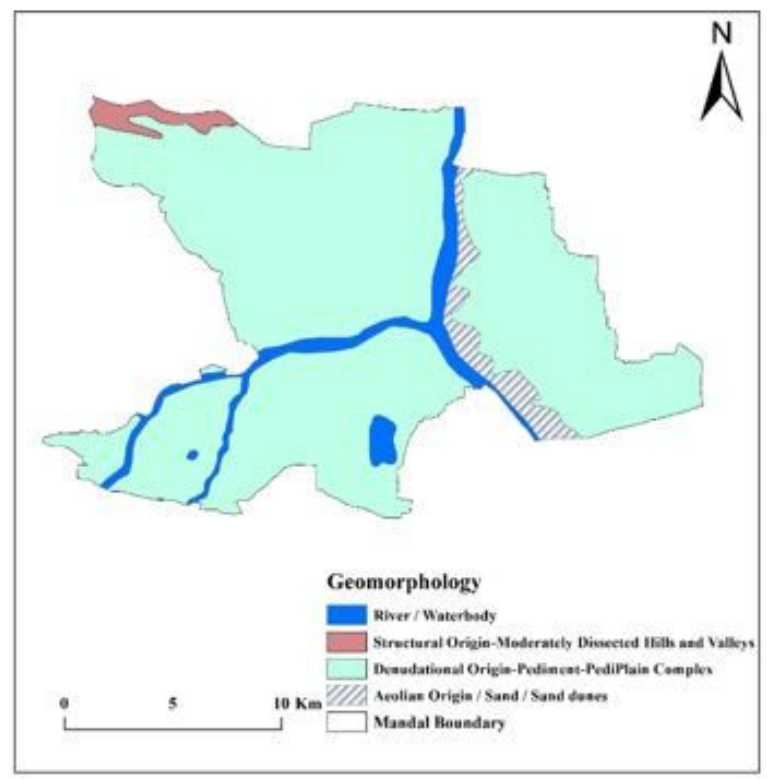

Figure 3

b: Geomorphology 


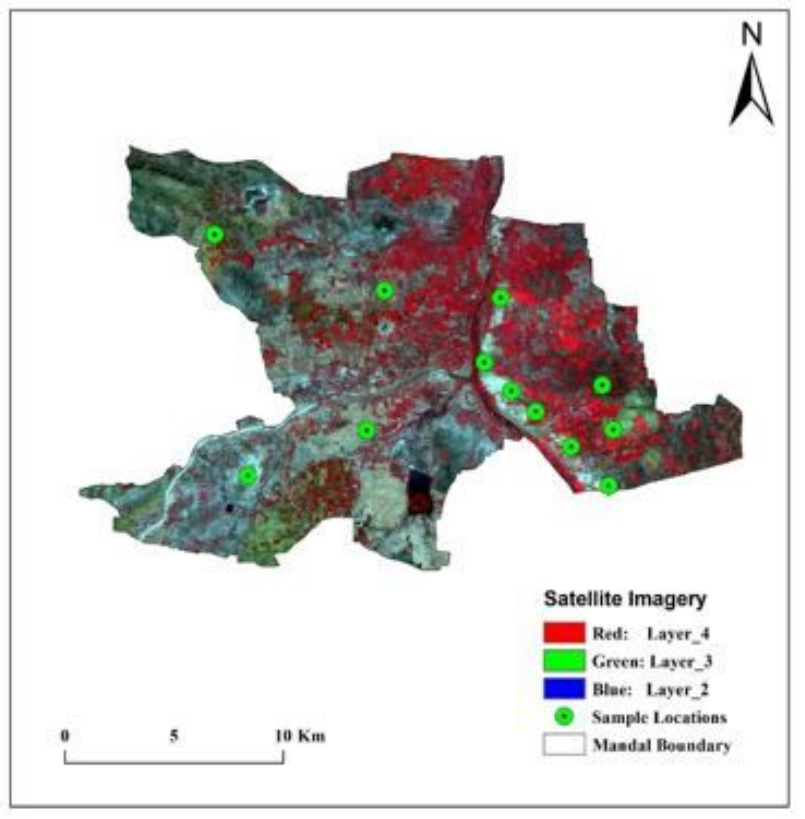

Figure 4

c: Soil sample location map

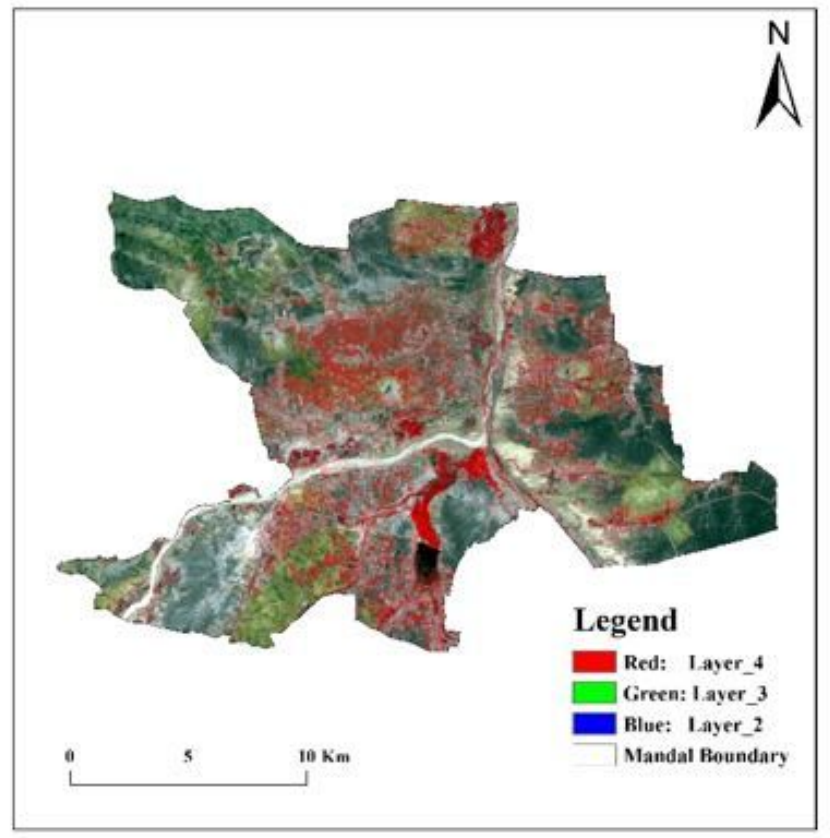

Figure 5

a: FCC of 1990 


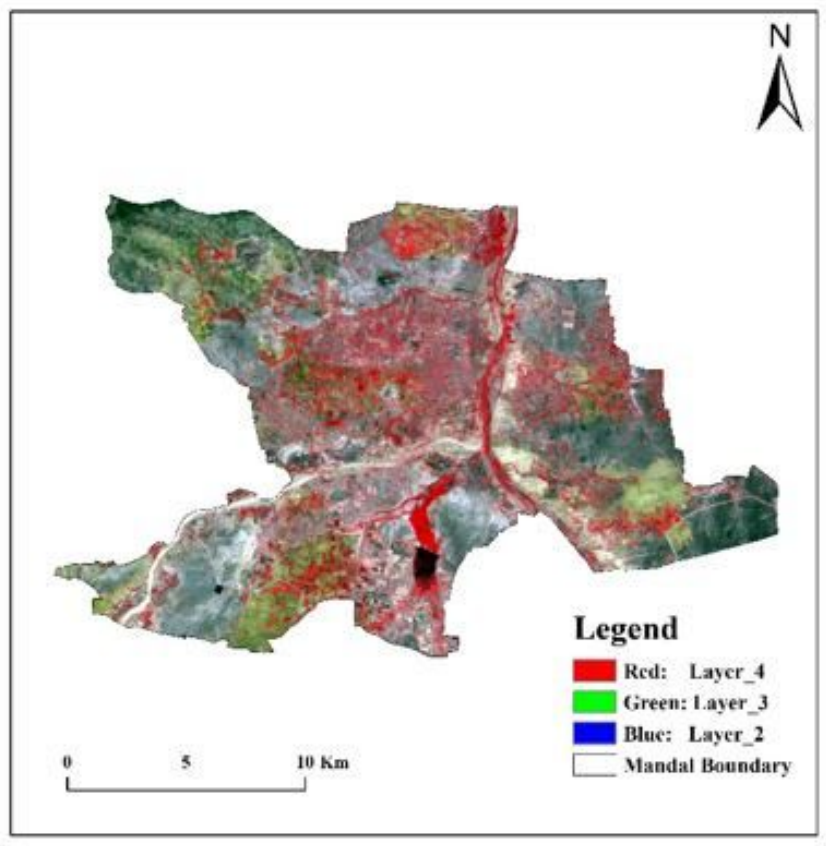

Figure 6

b: FCC of 2000

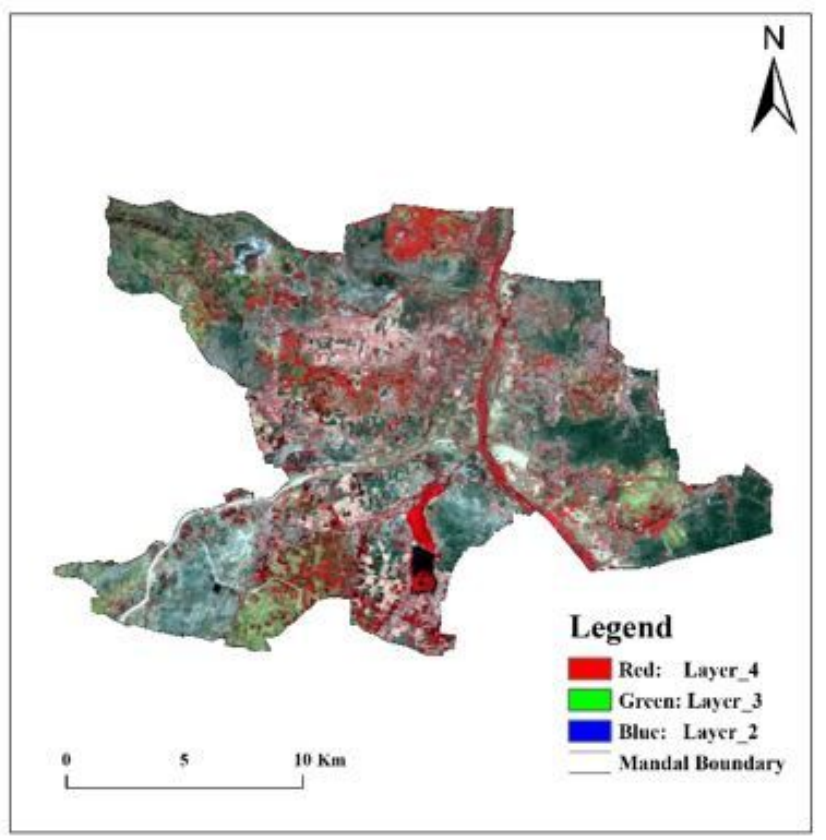

Figure 7

c: FCC of 2010 


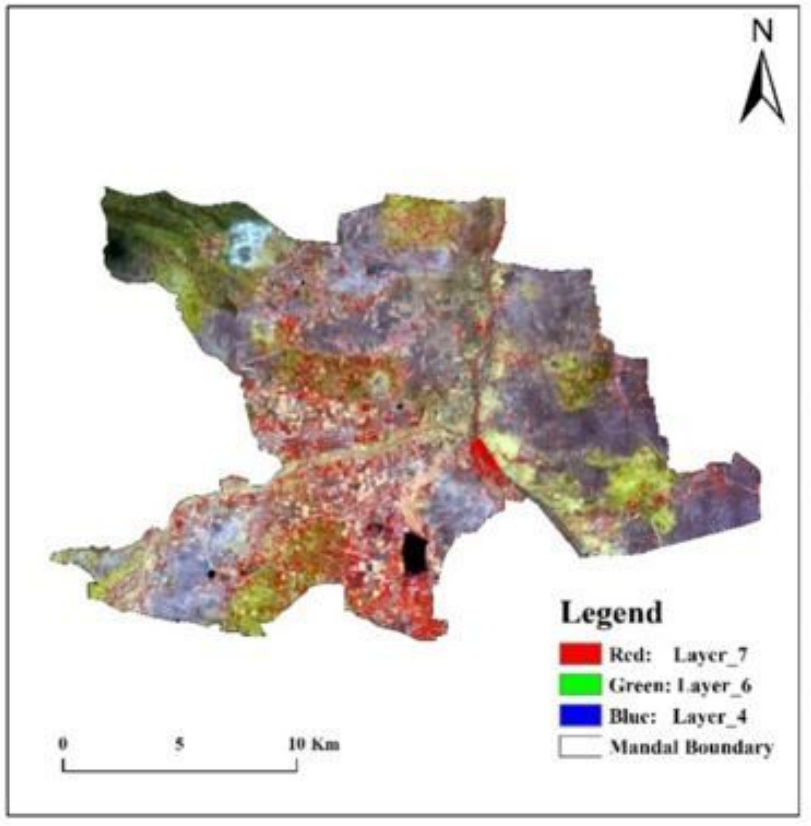

Figure 8

d: FCC of 2019

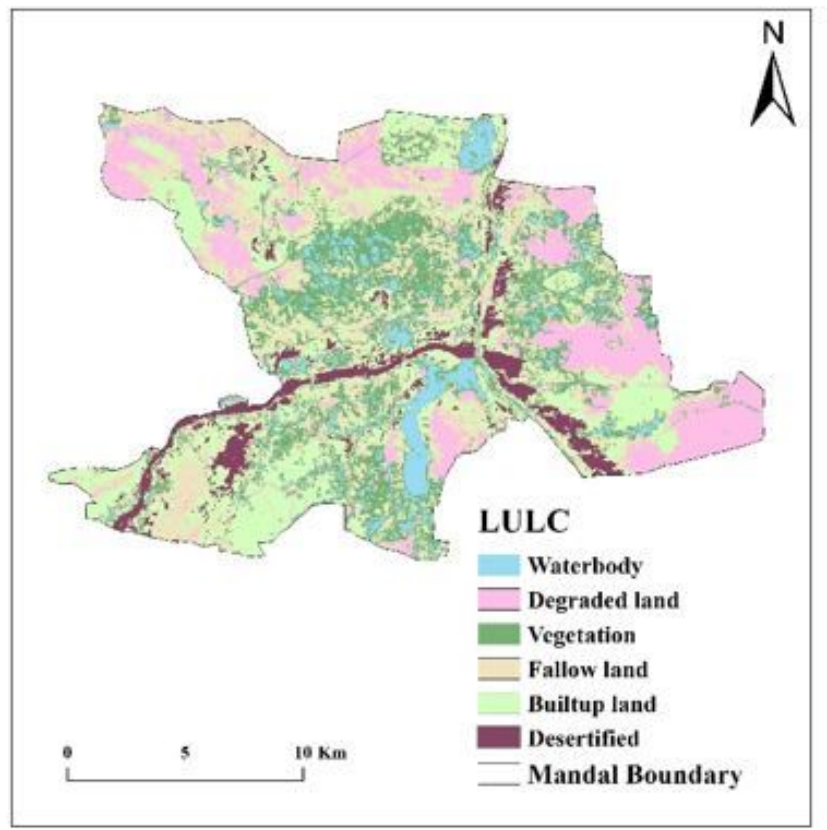

Figure 9

a: Unsupervised classification for 1990. 


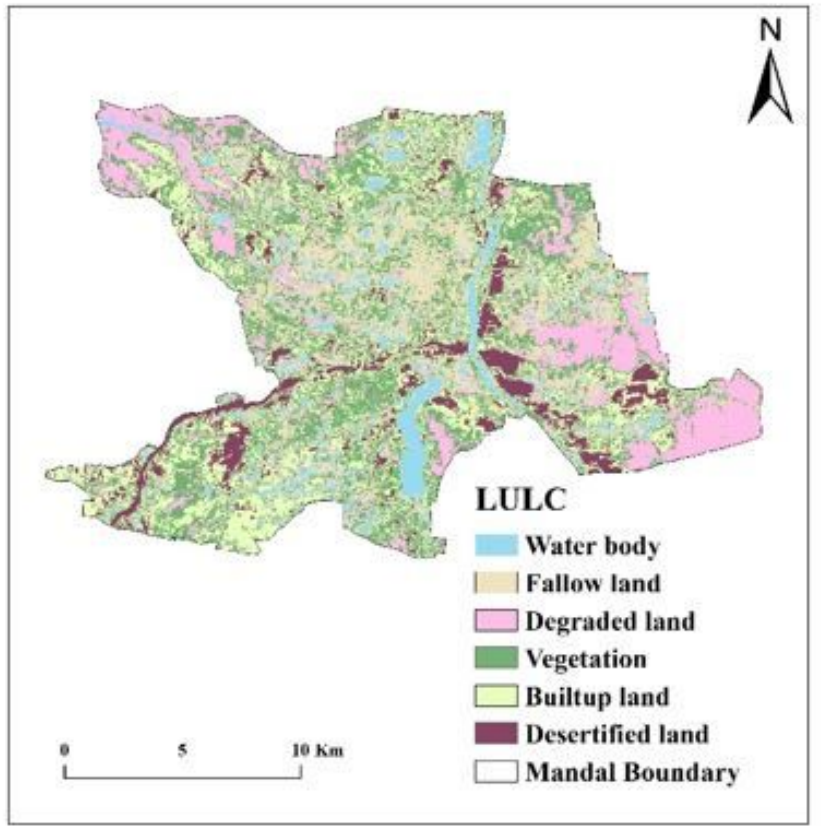

Figure 10

b: Unsupervised classification for 2000.

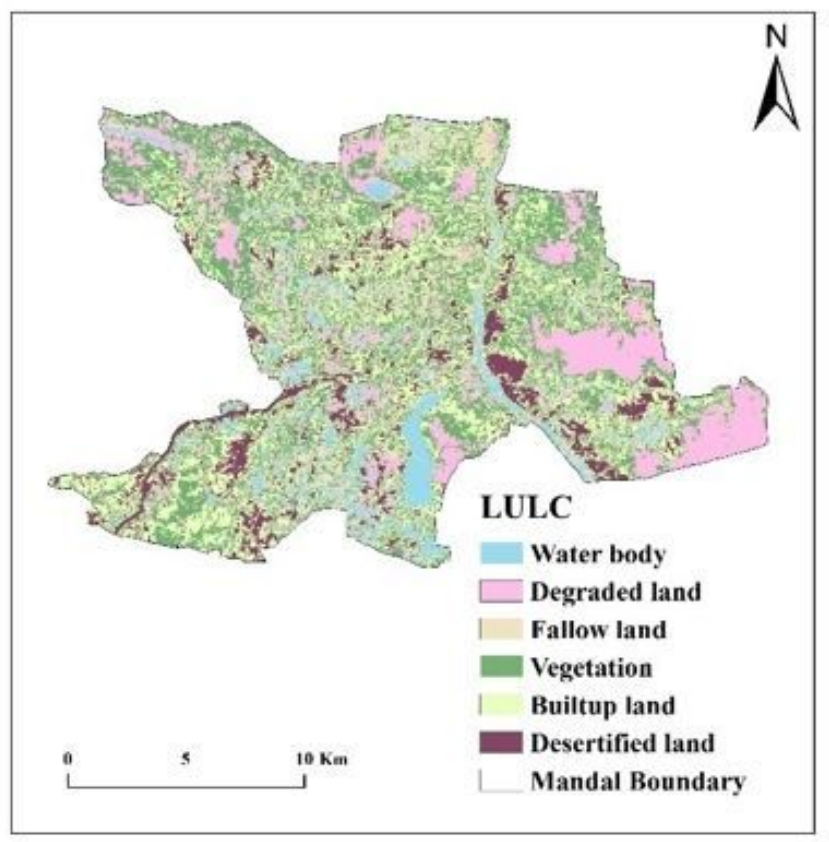

\section{Figure 11}

c: Unsupervised classification for 2010. 


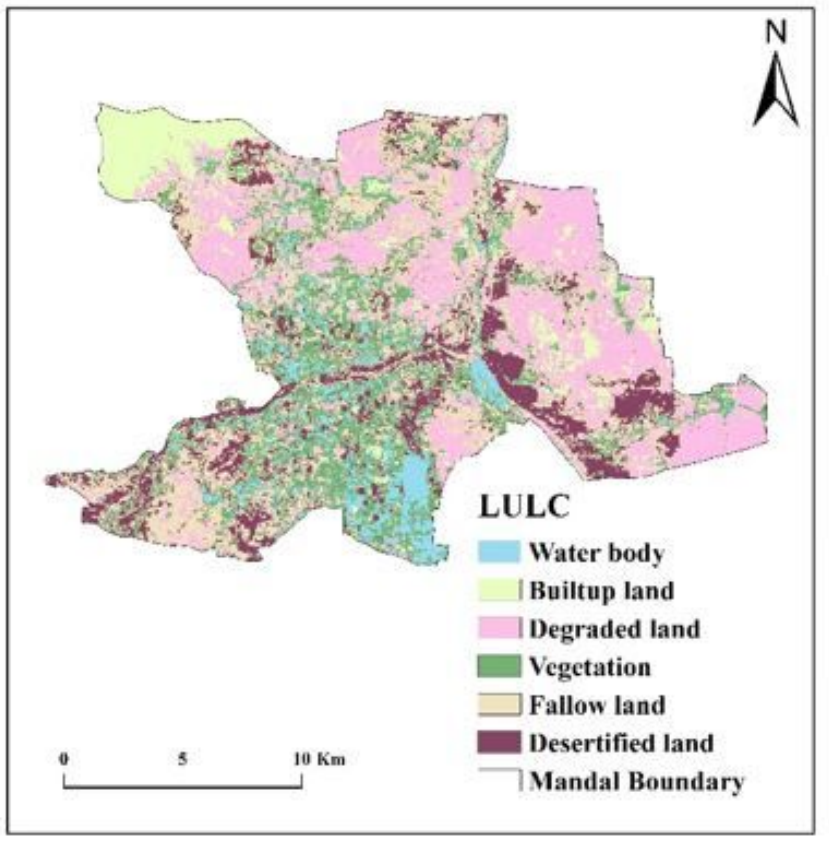

Figure 12

d: Unsupervised classification for 2019.

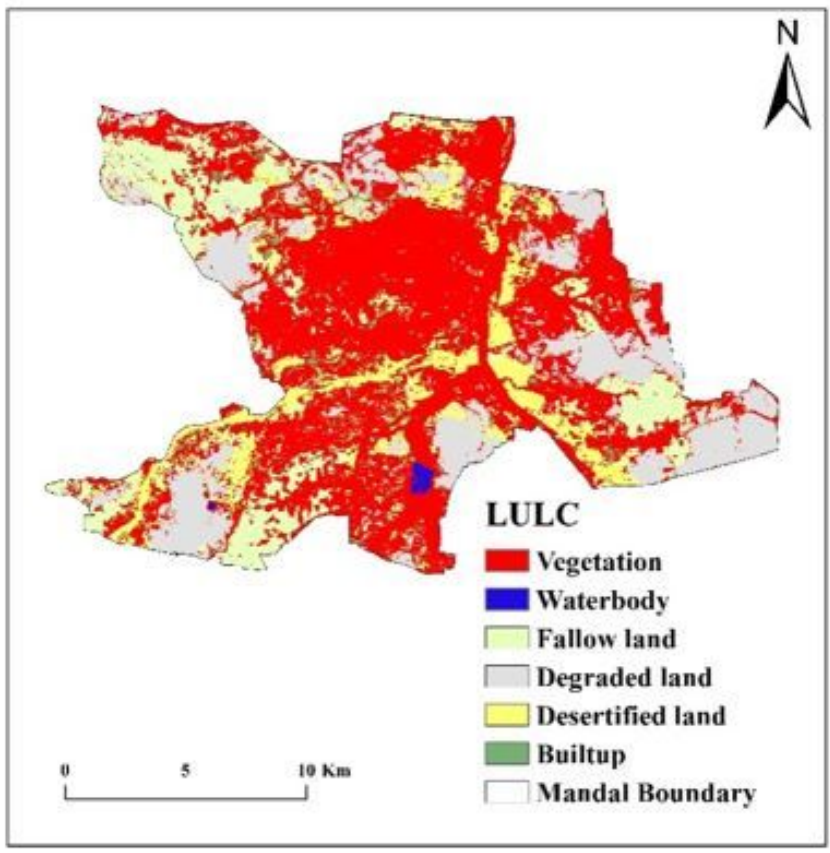

Figure 13

a: Supervised classification for 1990 . 


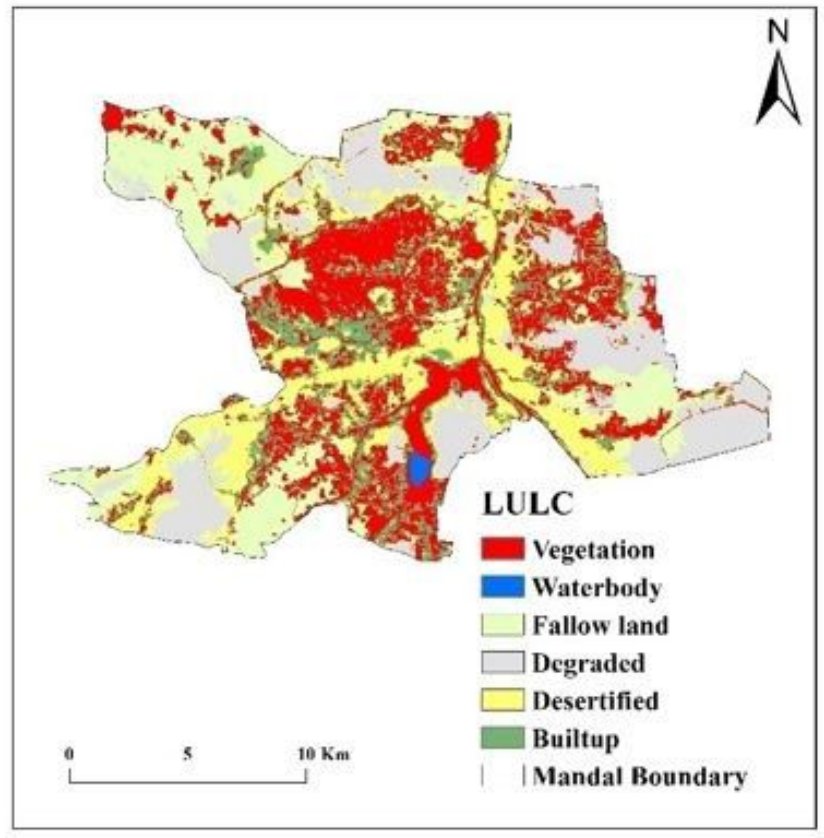

\section{Figure 14}

b: Supervised classification for 2000 .

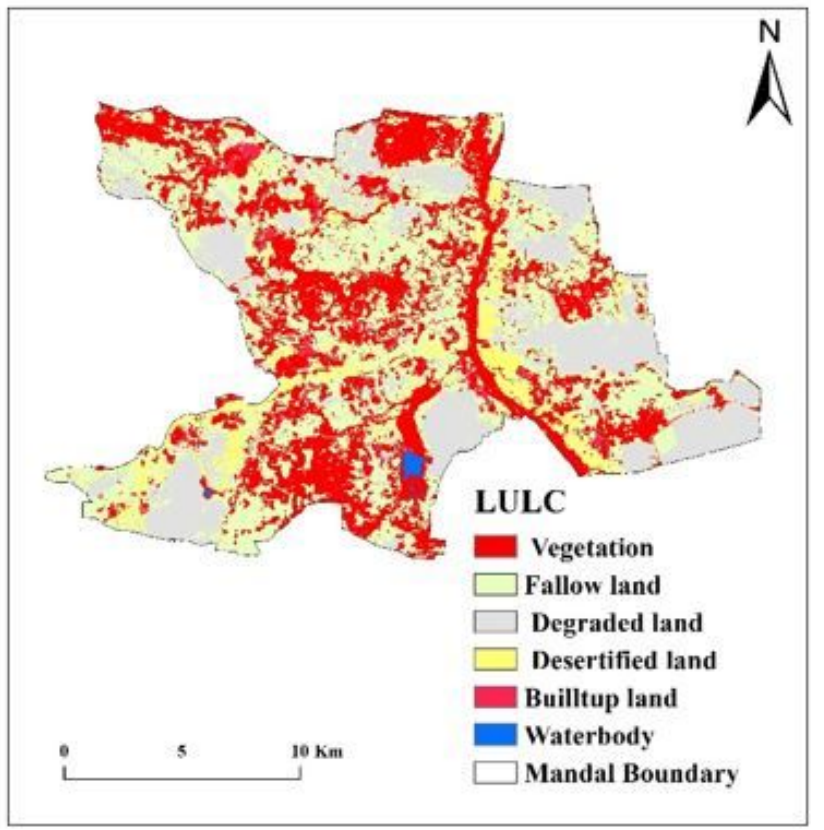

\section{Figure 15}

c: Supervised classification for 2010. 


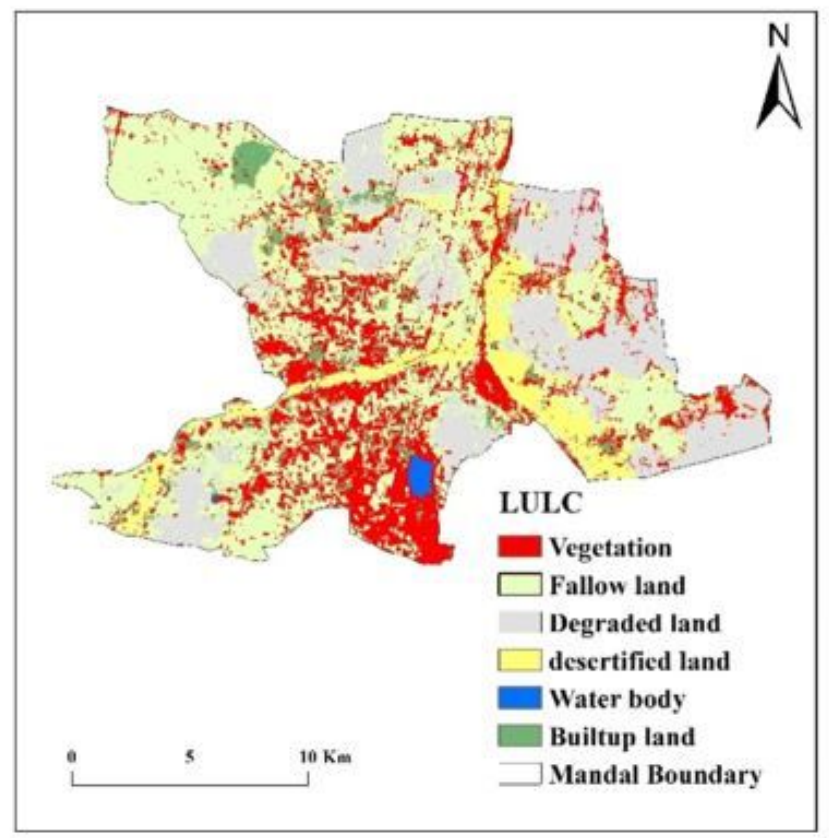

Figure 16

d: Supervised classification for 2019.

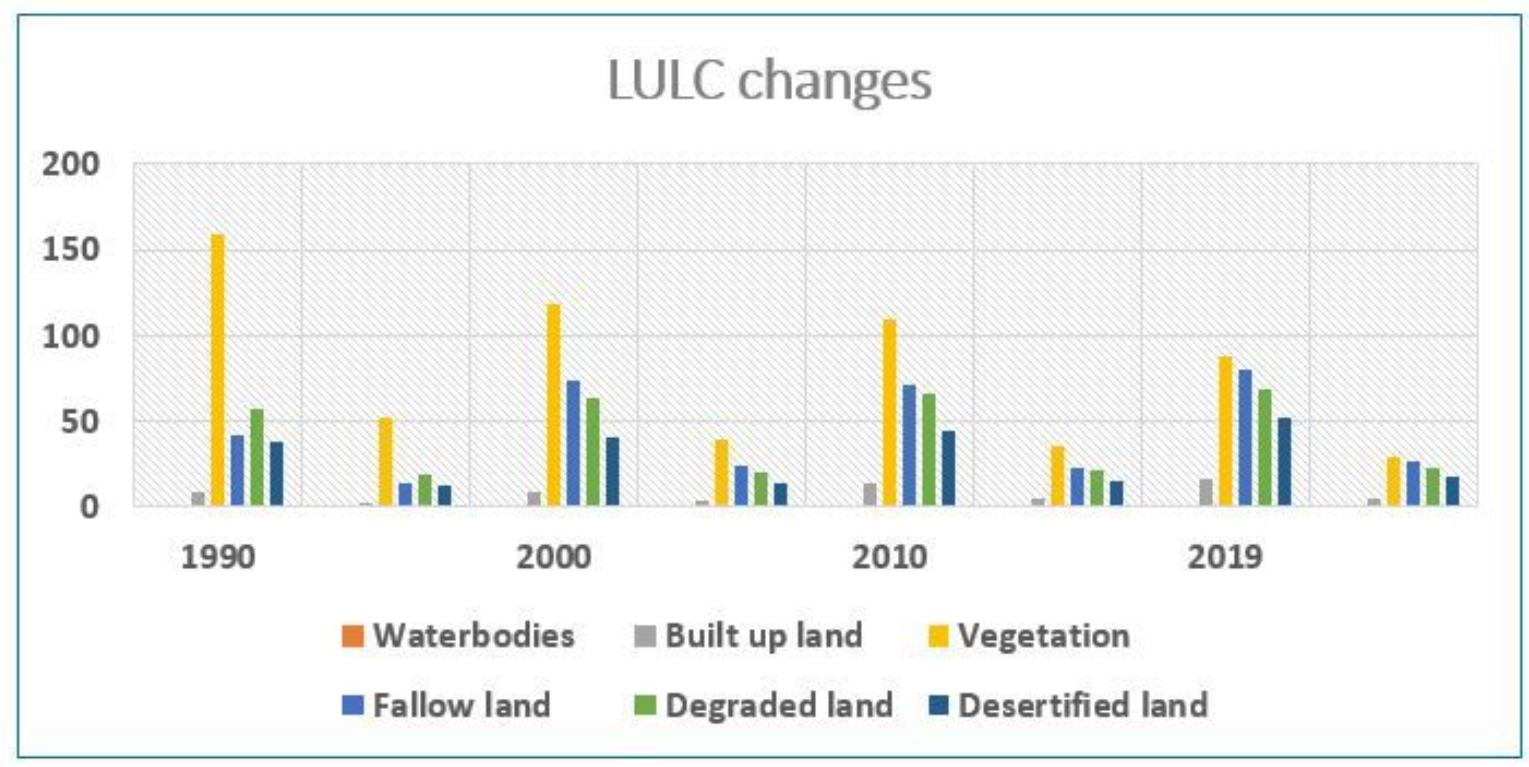

Figure 17

e: LULC changes from 1990 to 2019 in the graphical representation. 


\section{Changes from 1990 to 2019}

Changes from 2000-2019 Km2 Changes from 2000-2019 Percentage

60

40

20

0

$-20$

$-40$

$-60$

$-80$

\section{Figure 18}

f: LULC changes from 1990 to 2019 in the graphical representation.

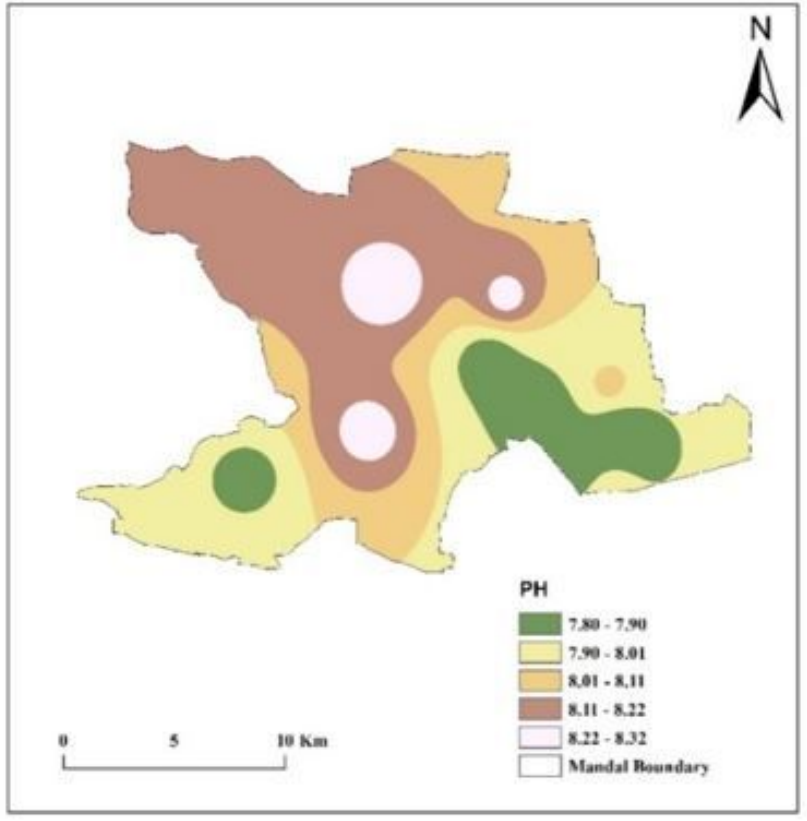

Figure 19

a: $\mathrm{pH}$ 


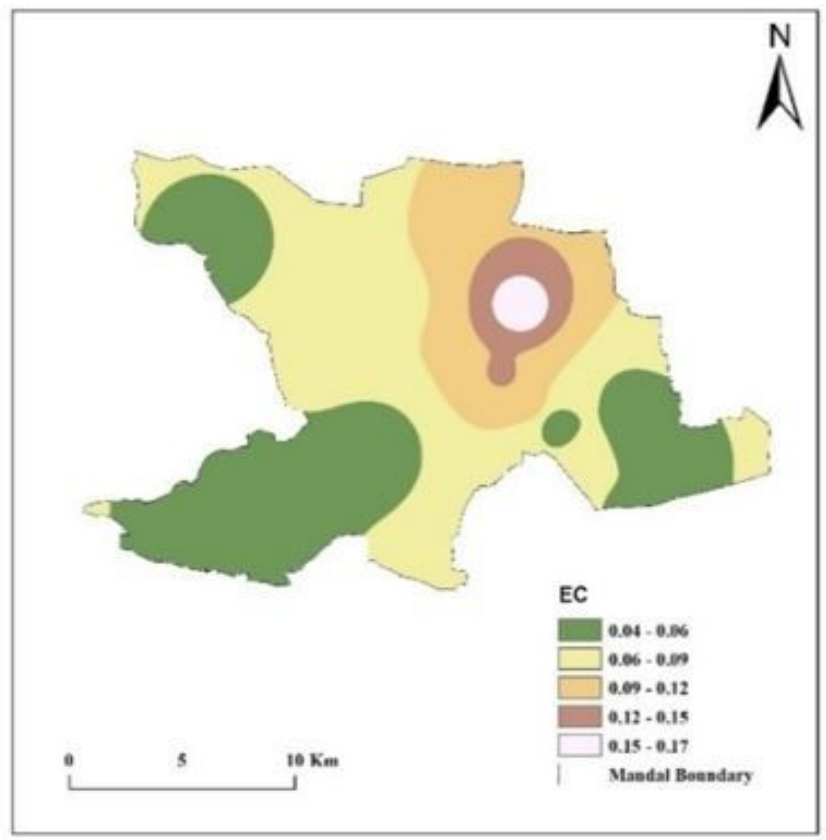

Figure 20

b: EC

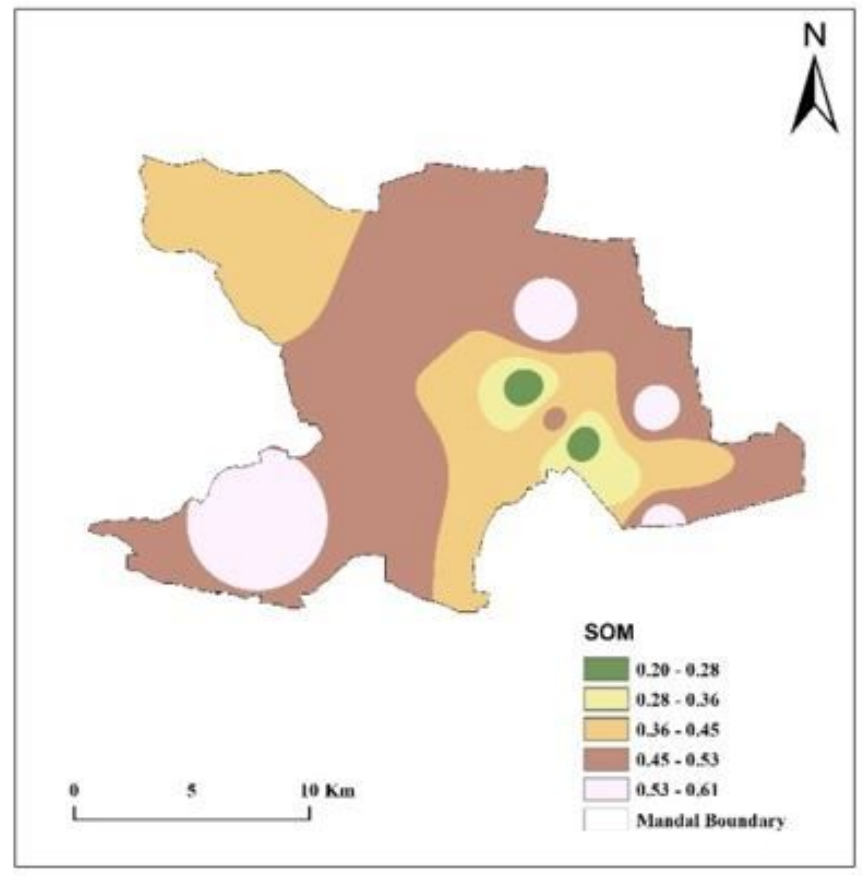

Figure 21

c: SOM 


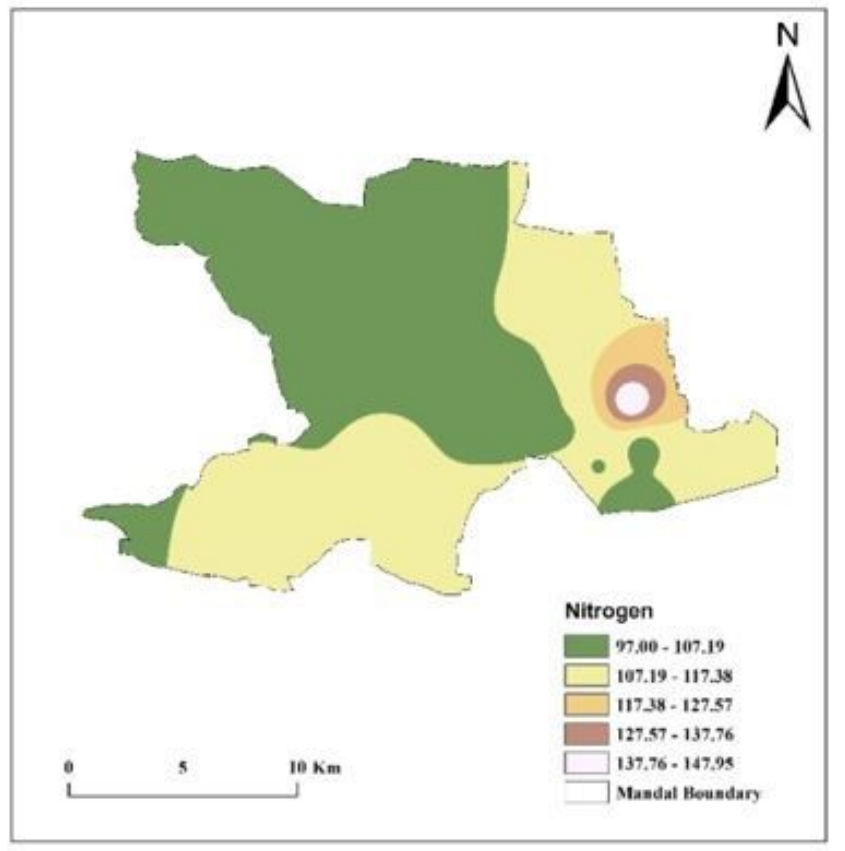

Figure 22

d: Nitrogen

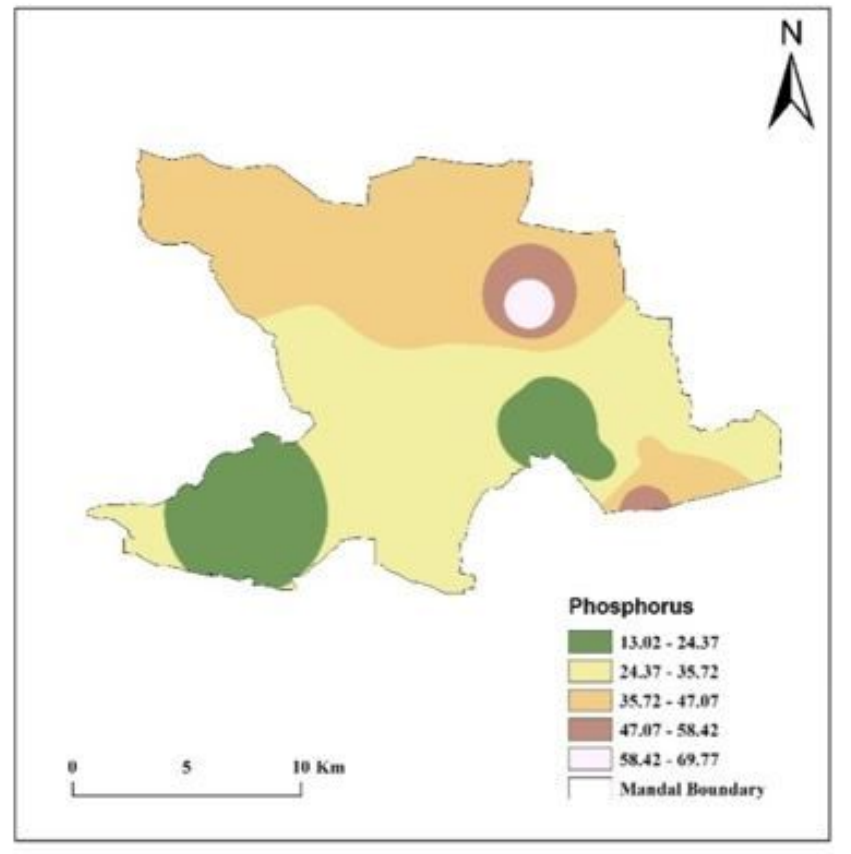

Figure 23

e: Phosphorus 


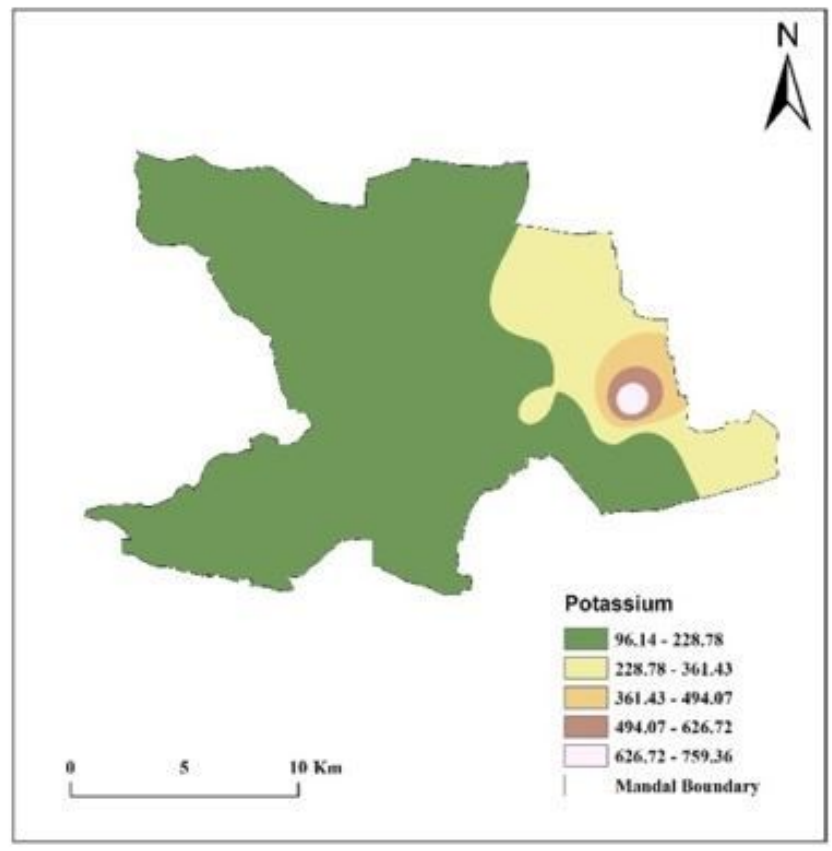

Figure 24

f: Potassium

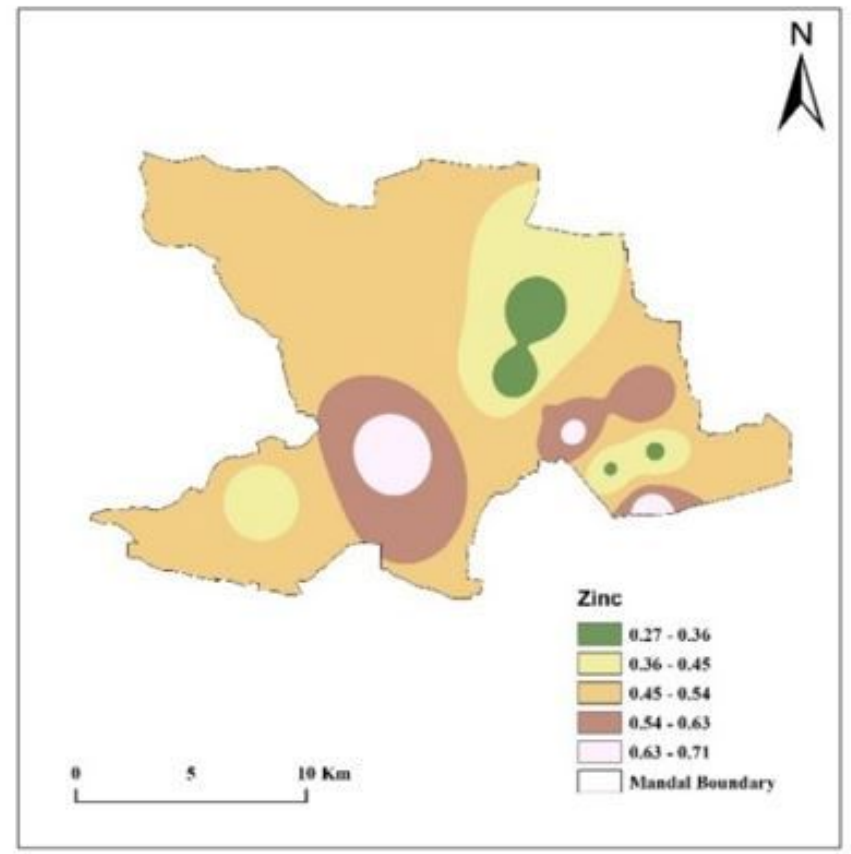

Figure 25

g: Zinc 


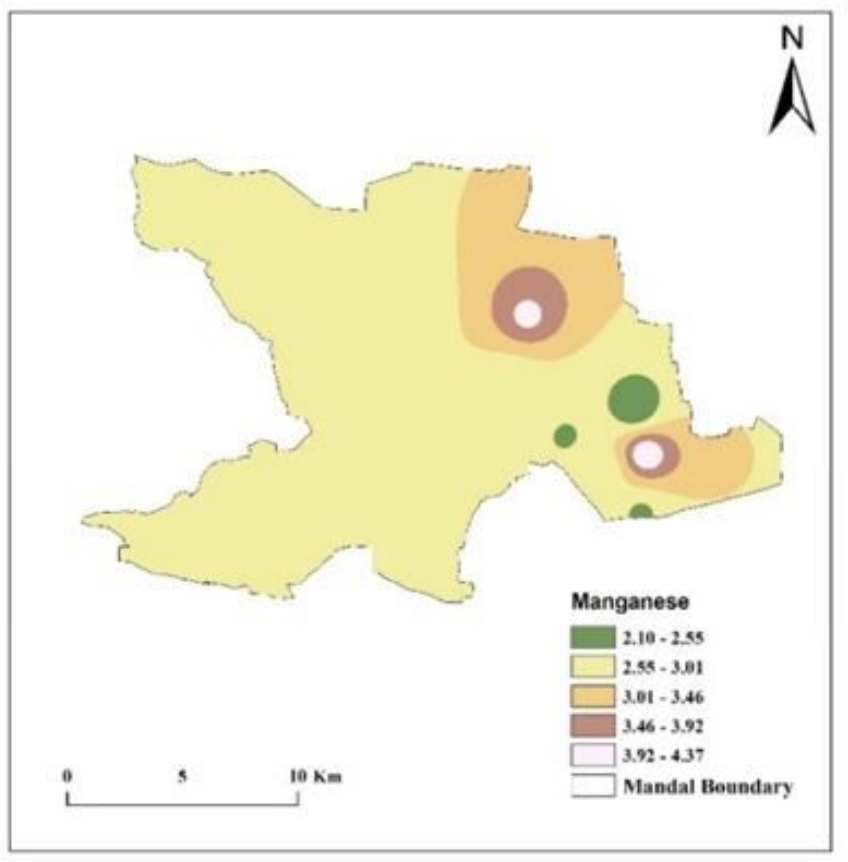

Figure 26

$\mathrm{h}: \mathrm{Mn}$

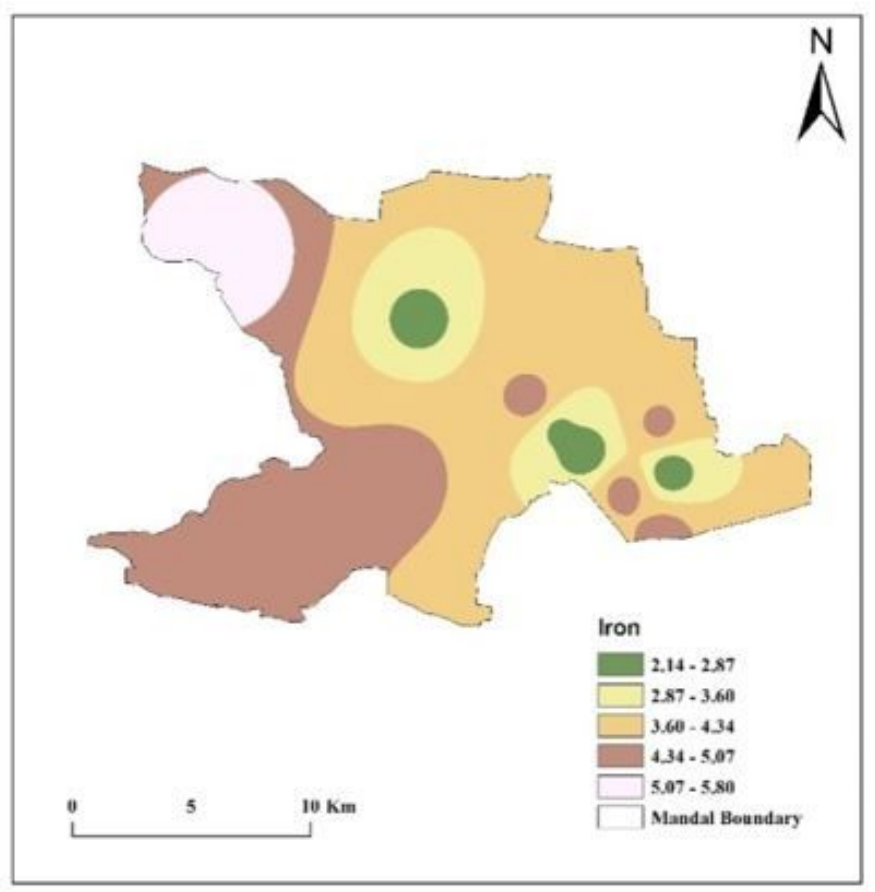

Figure 27

i: Iron 


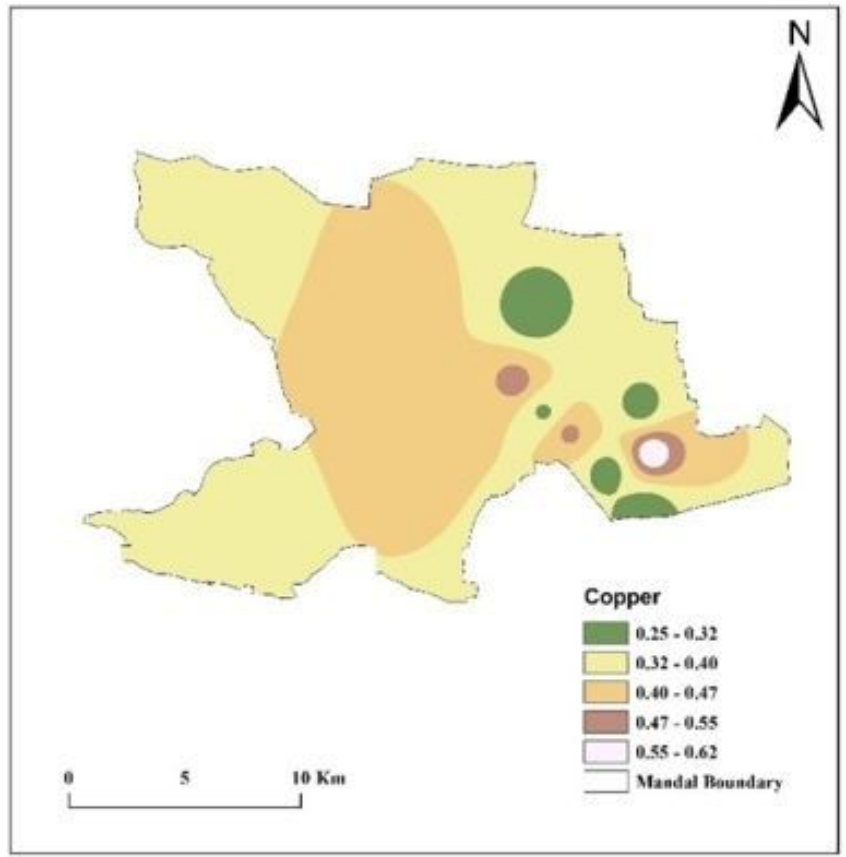

Figure 28

j: Copper

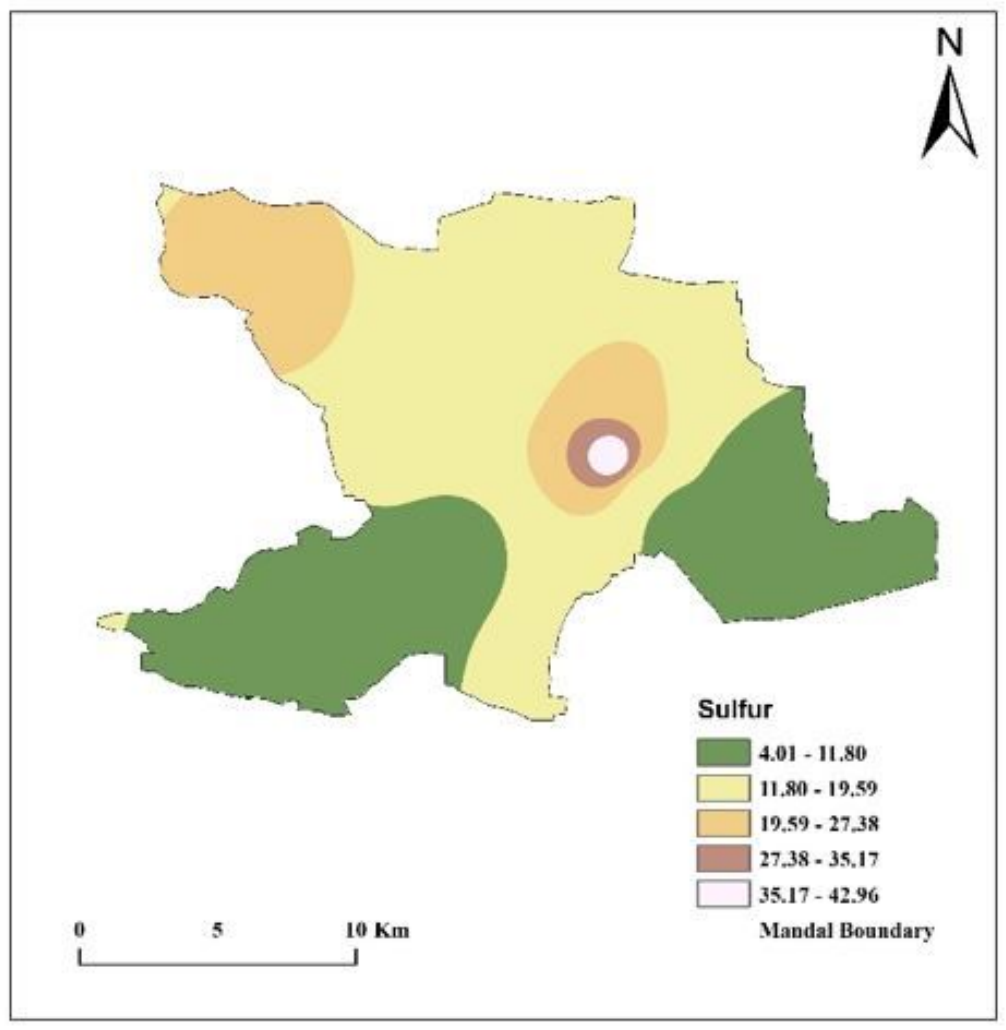

Figure 29

k: Sulphur 